\title{
Knowledge needs, available practices, and future challenges in agricultural soils
}

\author{
Georgina Key ${ }^{1}$, Mike G. Whitfield ${ }^{2}$, Julia Cooper ${ }^{3}$, Franciska T. De Vries ${ }^{1}$, Martin Collison ${ }^{4}$, \\ Thanasis Dedousis ${ }^{5}$, Richard Heathcote ${ }^{6}$, Brendan Roth ${ }^{7}$, Shamal Mohammed ${ }^{8}$, Andrew Molyneux ${ }^{9}$, \\ Wim H. Van der Putten ${ }^{10}$, Lynn V. Dicks ${ }^{11}$, William J. Sutherland ${ }^{11}$, and Richard D. Bardgett ${ }^{1}$ \\ ${ }^{1}$ School of Earth and Environmental Sciences from Faculty of Life Sciences, Michael Smith Building, \\ The University of Manchester, Oxford Road, Manchester, M13 9PL, UK \\ ${ }^{2}$ Lancaster Environment Centre, Lancaster University, Lancaster, LA1 4YQ, UK \\ ${ }^{3}$ School of Agriculture, Food and Rural Development, Newcastle University, Kings Road, \\ Newcastle upon Tyne, NE1 7RU, UK \\ ${ }^{4}$ Collison and Associates Limited, Honeysuckle Cottage, Shepherdsgate Road, Tilney All Saints, King's Lynn, \\ Norfolk, PE34 4RW, UK \\ ${ }^{5}$ European Agro Development Team, PepsiCo Europe, Rue du Rhône 50, 1204 Geneva, Switzerland \\ ${ }^{6}$ Richard Heathcote, R \& J Sustainability Consulting Ltd, working with: National Association of Cider Makers, \\ Cool Farm Alliance, and Innovate UK, 21 Lattimore Road, Stratford-upon-Avon, CV37 0RZ, UK \\ ${ }^{7}$ Department for Environment, Food \& Rural Affairs, Nobel House, 17 Smith Square, London, SW1P 3JR, UK \\ ${ }^{8}$ GeoInfo Fusion Ltd, Cranfield, Bedford, MK43 0DG, UK \\ ${ }^{9}$ Huntapac Produce Ltd, 293 Blackgate Lane, Holmes, Tarleton, Preston, Lancashire, PR4 6JJ, UK \\ ${ }^{10}$ Netherlands Institute of Ecology, Department of Terrestrial Ecology and Laboratory of Nematology, \\ Wageningen University and Research Centre, Droevendaalsesteeg 10, 6708 PB Wageningen, the Netherlands \\ ${ }^{11}$ Department of Zoology, University of Cambridge, Cambridge, CB2 3QZ, UK
}

Correspondence to: Georgina Key (georgina.key@ahdb.org.uk)

Received: 15 March 2016 - Published in SOIL Discuss.: 11 May 2016

Revised: 4 September 2016 - Accepted: 10 September 2016 - Published: 10 October 2016

\begin{abstract}
The goal of this study is to clarify research needs and identify effective practices for enhancing soil health. This was done by a synopsis of soil literature that specifically tests practices designed to maintain or enhance elements of soil health. Using an expert panel of soil scientists and practitioners, we then assessed the evidence in the soil synopsis to highlight practices beneficial to soil health, practices considered detrimental, and practices that need further investigation. A partial Spearman's correlation was used to analyse the panel's responses. We found that increased certainty in scientific evidence led to practices being considered to be more effective due to them being empirically justified. This suggests that for practices to be considered effective and put into practice, a substantial body of research is needed to support the effectiveness of the practice. This is further supported by the high proportion of practices (33\%), such as changing the timing of ploughing or amending the soil with crops grown as green manures, that experts felt had unknown effectiveness, usually due to insufficiently robust evidence. Only 7 of the 27 reviewed practices were considered to be beneficial, or likely to be beneficial in enhancing soil health. These included the use of (1) integrated nutrient management (organic and inorganic amendments); (2) cover crops; (3) crop rotations; (4) intercropping between crop rows or underneath the main crop; (5) formulated chemical compounds (such as nitrification inhibitors); (6) control of traffic and traffic timing; and (7) reducing grazing intensity. Our assessment, which uses the Delphi technique, is increasingly used to improve decision-making in conservation and agricultural policy, identified practices that can be put into practice to benefit soil health. Moreover, it has enabled us to identify practices that need further research and a need for increased communication between researchers, policy-makers, and practitioners, in order to find effective means of enhancing soil health.
\end{abstract}




\section{Introduction}

Soil health in agroecosystems describes the continued ability of a soil to sustain crop (or animal) growth over the long-term through efficient recycling and provision of nutrients and water and is controlled by a variety of factors and their interactions, including soil physical and chemical properties, soil organic matter, and the activities of diverse soil biological communities (Maeder et al., 2002; Bardgett, 2002; Barrios, 2007; Kibblewhite et al., 2008; Lamarque et al., 2011). Enhancing soil health is central to delivering food security and ecosystem services (Lal, 2009; De Vries et al., 2012; Lipper et al., 2014). As agriculture has become increasingly intensified, and agroecosystems less biologically diverse, the ecosystem processes underpinning soil health are deteriorating (Glover et al., 2010; Amundson et al., 2015; FAO and ITPS, 2015; Bardgett, 2016). In addition to food production, healthy soils also underpin a wide range of ecosystem services, including carbon sequestration, flood control, and biological control of pests and diseases (Lavelle et al., 2006; Wall et al., 2012; FAO and ITPS, 2015; Bardgett, 2016), which are crucial to underpinning sustainable development goals (Keesstra et al., 2016).

Soil degradation is caused by many factors, including deforestation, infrastructure development, and construction, but inappropriate management of agricultural land is also a major cause (Terranova et al., 2009; Nunes et al., 2011). For example, increased mechanization and size of farm machinery has caused extensive soil compaction (a major factor in soil degradation) (Beylich et al., 2010; Allman et al., 2015); continuous tillage, which disrupts soil structure and increases soil organic matter loss, has accelerated rates of soil erosion in parts of the world (Martinez-Casasnovas and Ramos, 2009; Don et al., 2010; Crittenden et al., 2015); heavy grazing by livestock leaves land sparsely vegetated, compacted, and vulnerable to soil erosion (Lal, 1990; Nunes et al., 2011); and leaving cropland without a protective vegetative cover causes declines in soil organic matter content and leaves soil exposed to the erosive forces of wind and rain (Lal, 1990; Pimentel et al., 1995). Evidence is accumulating that intensive farming practices reduce the diversity and complexity of soil food webs (Tsiafouli et al., 2016), which has consequences for the functioning of soil and its ability to buffer against extreme weather events (De Vries et al., 2012).

While many practitioners are well versed in how to maintain soil health, they are often not aware of the trade-offs that exist between enhancing certain soil properties and maintaining the functions that underpin them. For example, relatively little is known about how farming practices influence the diversity and functioning of complex soil microbial communities that are responsible for transforming nutrients into plantavailable forms or what can be done to harness the benefits of soil organism activities for soil health and crop production
(Philippot et al., 2013; Bardgett and van der Putten, 2014). Also, management practices that have been shown to maintain many ecosystem services in tandem with soil fertility, such as mulching, composting, and specific crop rotations, might not markedly benefit soil biodiversity (Turbé et al., 2010). There is also much discussion about how to best manage for soil health, resulting in the need for evidence-based environmental policies for sustainable soil management, as well as the identification of knowledge needs for researchers and practitioners.

The overall goal of this paper was to identify effective practices for enhancing soil health and clarify future research needs. This was done by a synopsis of soil literature that specifically tests practices designed to maintain or enhance elements of soil health. Using an expert panel of soil scientists and practitioners, we then assessed the evidence in the soil synopsis to highlight practices beneficial and detrimental to soil health and practices that need further investigation. We used the Delphi technique (Mukherjee et al., 2015) to produce a ranked list of current evidence-based practices for enhancing soil health (Sutherland et al., 2004, 2011). The Delphi technique is a data synthesis method that seeks to find a consensus between experts on a particular subject (Hsu and Sandford, 2007). It is widely used in medicine to clarify particular issues, assess gaps in knowledge, enhance decisionmaking, and inform policy (Jones and Hunter, 1995; Hasson et al., 2000; Hsu and Sandford, 2007). However, it also presents opportunities to improve decision-making in conservation and agricultural policy (Sutherland, 2006). For example, the Delphi technique was used to determine a package of best management practices to reduce nitrogen emissions from poultry units (Angus et al., 2003) and to quantify the effectiveness and certainty of evidence to determine beneficial practices for conservation (Walsh et al., 2013). We used the Delphi technique to identify and assess practices that benefit soil health.

\section{Methods}

We identified major threats to soil health, including erosion, reduced soil organic matter, soil compaction, nutrient leaching, and biodiversity loss, using lists compiled by the UK Soil Association (Marmo, 2012), the Department for Environment, Food and Rural Affairs (Defra, 2009), and Scottish Environment Protection Agency (SEPA, 2012). Additional threats (considered secondary threats by the aforementioned organizations) include carbon loss, pollution (via the addition of substances such as acids, nutrients, or metals), and flooding. To identify the scientific literature relevant to enhancing or maintaining soil health, we used two approaches: a literature search, using key search terms within a database, and a journal trawl whereby we examined every published article and manually selected relevant papers. For 
the literature search we used the Web of Science database (Thomson Reuters 2014), and search terms were chosen using an iterative process of searching and refining. The terms used in this search focused on practices to maintain or restore natural (or semi-natural) soil processes related to soil health. The initial searches returned 37748 hits. The first 100 titles for each search term were examined and the search refined. Duplicate studies were removed. All article titles and abstracts were examined and irrelevant references excluded. A panel of experts were selected to help refine the number of studies. They were chosen based on their expertise in their respective fields, to give a range of perspectives on the literature and to highlight potential issues either with the science or implementation of a practice. Study abstracts for the remaining 543 references were then scanned to identify studies meeting two criteria: (1) there was a practice that farmers or land managers could perform to enhance soil health on their land; and (2) effects of the practice were monitored quantitatively. These criteria excluded studies examining the effects of specific practices without testing them explicitly. For example, predictive modelling studies and correlative studies were excluded (Dicks et al., 2013b).

For the journal trawl, seven journals were selected based on the wide scope of their soil-related research and on the recommendation of experts in soil science. These included the European Journal of Soil Science, Geoderma, Global Change Biology, Land Use Policy, Soil Biology and Biochemistry, Soil Use and Management, and the Journal of Applied Ecology. Study titles and abstracts were scanned from volume 1 of each journal to mid-2012. The trawl identified 175 studies relevant to all soil health practices. These literature review methods together returned a total of 718 studies monitoring the effects of practices in the list. As this was part of a project looking at how to increase food security, we included European studies and regions with similar temperate climates where similar agricultural practices were used. The majority of our papers relate to farming in temperate regions of the world, especially Europe and the US; our references are therefore only a sample of the global literature but nonetheless represent a substantial body of evidence and include a broad spectrum of journals that publish soil-related research.

The literature was distilled into a synopsis of practices for enhancing soil health, available online (http://www. nercsustainablefood.com, http://www.conservationevidence. com) and in Key et al. (2015). The list of 27 practices to enhance soil health was developed from a list suggested by several academics who work in relevant fields and who were not part of the Expert Panel (see below). These practices were refined and added to as we reviewed the literature. Practices were included if they could realistically be adopted by farmers and land managers, regardless of whether they had already been adopted or whether or not evidence for their effectiveness already existed. We consulted farmers and land managers, as to whether it was feasible or likely that a prac- tice would be implemented. All captured studies relevant to soil health were included. The review was carried out over a short time frame in 2012. The Expert Panel then took part in the Delphi Assessment of the review in 2013.

The Expert Panel consisted of three experts from academia, three from private-sector research, one from a governmental body, one from an agricultural consultancy, and one from agribusiness. All have expertise in soil research and land management, and each of them provided an independent assessment of the evidence for each practice. They were asked to participate because they were either primary stakeholders or decision makers and because they all have specialized knowledge in soil management (Hsu and Sandford, 2007). Expert panels range widely in number. In an assessment of the effectiveness of various conservation measures, expert panel numbers ranged from 4 to 47 members (Sutherland et al., 2015), whereas in a systematic review of healthcare quality indicators, the average number of panel members was 17 (Boulkedid et al., 2011). Here, we had nine panel members who were asked to allocate a score to each practice using the online survey software Qualtrics (http://www.qualtrics.com). Their assessment was based on four factors: the effectiveness of each practice in enhancing soil health; certainty in the evidence for each practice; the strength of potential negative side effects associated with implementing the practice; and finally soil types and locations covered. The panel were asked to ignore prior knowledge of effectiveness and base their scoring only on the evidence presented in the synopsis.

The Delphi technique was used to quantify effectiveness of the practices and certainty of evidence (Rowe and Wright, 1999; Hutchings and Raine, 2006). In this technique, the panel completes a repeated, anonymous survey of evidence to elicit an expert judgement on a complex problem (Mukherjee et al., 2014). The number of panel members used in the Delphi technique can vary, but the average of several experts' opinions is likely to be more reliable than an individual assessment of a problem (Sutherland et al., 2015). This paper extends work by Sutherland et al. (2011), in which the technique was applied to conservation in agroecosystems to promote evidence-based practice (Sutherland et al., 2004). The Expert Panel members independently scored the four factors listed above using a percentage scale for each practice for the first round of scoring and then received the collated evidence from the rest of the Expert Panel, with the aim of collaboratively refining the judgements of each panel member (Walsh et al., 2013). The ability of panel members to see each other's (anonymous) comments can lead to a refining of opinions and allow the panel to approach decision-making using another perspective (Hasson et al., 2000). Based on the differing perspectives encountered, each expert then entered final assessments for each of the practices and comments were recorded. One advantage of using Qualtrics is that final scores were not unduly influenced by dominant personalities (Sutherland, 2006; Burgman et al., 2011). The order in 
Table 1. The 27 practices for enhancing soil health ranked according to the median of final scores (1-100) by scientists, practitioners and policy-makers, from most beneficial through to harmful. The scores have been used to put the practices into six indicative categories, based on categories of effectiveness by Sutherland et al. (2015): (1) beneficial; (2) likely to be beneficial; (3) trade-offs between benefits and adverse side effects; (4) unknown effectiveness; (5) unlikely to be beneficial; (6) likely to be ineffective or to have adverse side effects.

\begin{tabular}{|c|c|c|c|c|c|}
\hline & Practice & Effectiveness & Certainty & $\begin{array}{l}\text { Negative } \\
\text { side effects }\end{array}$ & Category \\
\hline 1 & Amend the soil using integrated nutrient management & 69 & 64 & 15 & Beneficial \\
\hline 2 & Grow cover crops & 75 & 67 & 16 & Beneficial \\
\hline 3 & Use crop rotation & 66 & 75 & 8 & Beneficial \\
\hline 1 & $\begin{array}{l}\text { Grow cover crops beneath the main crop (living mulches) } \\
\text { or between crop rows }\end{array}$ & 65 & 54 & 19 & Likely to be beneficial \\
\hline 2 & Amend the soil with formulated chemical compounds & 64 & 46 & 19 & Likely to be beneficial \\
\hline 3 & Control traffic and traffic timing & 55 & 62 & 18 & Likely to be beneficial \\
\hline 4 & Reduce grazing intensity & 51 & 58 & 14 & Likely to be beneficial \\
\hline 1 & Change tillage practices & 61 & 72 & 46 & Trade-offs \\
\hline 2 & Convert to organic farming & 55 & 52 & 64 & Trade-offs \\
\hline 3 & Manuring and composting & 70 & 59 & 26 & Trade-offs \\
\hline 4 & Mulching & 60 & 64 & 23 & Trade-offs \\
\hline 5 & Retain crop residues & 63 & 54 & 29 & Trade-offs \\
\hline 6 & Restore or create low-input grasslands & 53 & 59 & 32 & Trade-offs \\
\hline 7 & Amend the soil with municipal wastes or their composts & 45 & 44 & 54 & Trade-offs \\
\hline 8 & Amend the soil with fresh plant material or crop remains & 53 & 53 & 34 & Trade-offs \\
\hline 9 & Incorporate leys into crop rotation & 46 & 45 & 36 & Trade-offs \\
\hline 10 & Plant new hedges & 49 & 45 & 20 & Trade-offs \\
\hline 1 & Change the timing of ploughing & 46 & 38 & 33 & Unknown effectiveness \\
\hline 2 & Amend the soil with organic processing wastes or their composts & 58 & 35 & 20 & Unknown effectiveness \\
\hline 3 & Change the timing of manure application & 50 & 33 & 24 & Unknown effectiveness \\
\hline 4 & Amend the soil with crops grown as green manures & 53 & 36 & 16 & Unknown effectiveness \\
\hline 5 & Amend the soil with composts not otherwise specified & 54 & 29 & 19 & Unknown effectiveness \\
\hline 6 & Amend the soil with non-chemical minerals and mineral wastes & 35 & 37 & 23 & Unknown effectiveness \\
\hline 7 & Amend the soil with bacteria or fungi & 40 & 31 & 17 & Unknown effectiveness \\
\hline 8 & Use alley cropping & 36 & 23 & 19 & Unknown effectiveness \\
\hline 9 & Encourage foraging waterfowl & 14 & 34 & 20 & Unknown effectiveness \\
\hline 1 & Reduce fertilizer, pesticide use & 26 & 40 & 48 & Likely to be ineffective or harmful \\
\hline
\end{tabular}

which practices were presented was varied to prevent panel bias in scoring from order of presentation. All scoring took place remotely via the Qualtrics website.

The 27 practices for enhancing soil health were then ranked according to the median of the final scores, as assessed by the expert panel. The scores were used to put the practices into six categories, following the method described by Sutherland et al. (2015): (1) beneficial (in enhancing soil health); (2) likely to be beneficial; (3) trade-offs between benefits and adverse side effects; (4) unknown effectiveness; (5) unlikely to be beneficial; and (6) likely to be ineffective or to have adverse side effects. The categories are based on threshold values of certainty, effectiveness, and negative side effects, i.e. on a combination of the benefit and harm and the strength of the evidence (Supplement, Table 1).

Due to the relatively low number of practices, we used a partial Spearman's correlation to analyse the Expert Panel's assessment to identify any relationship between the certainty of the evidence and the perceived effectiveness of each practice. We used the ppcor package (Kim, 2012) in R, version 3.1.1 (R Core Team, 2014). The median scores for the effectiveness of each practice and certainty of evidence were the main variables, with the strength of potential negative side effects from implementing the practices as the controlled variable.

\section{Results}

The 27 practices assessed by the Expert Panel were ranked by how beneficial each practice is to soil health (Table 1 and Supplement).

Of the 27 practices, only three were considered to be unequivocally beneficial to soil health, namely the use of a mix of organic and inorganic soil amendments, growing cover crops, and crop rotation. The three practices found to be beneficial had the highest certainty and effectiveness scores, along with good coverage in the literature (Fig. 1) and weak negative side effects. Four of the practices were considered likely to be beneficial, namely growing cover crops beneath the main crop (living mulches) or intercropped; amending the soil with formulated chemical compounds; controlling traffic and traffic timing; and reducing grazing intensity. However, they received lower certainty and effectiveness scores, due in part to the smaller body of evidence available. The only practice that fell into the "likely to be ineffective or harmful" cat- 


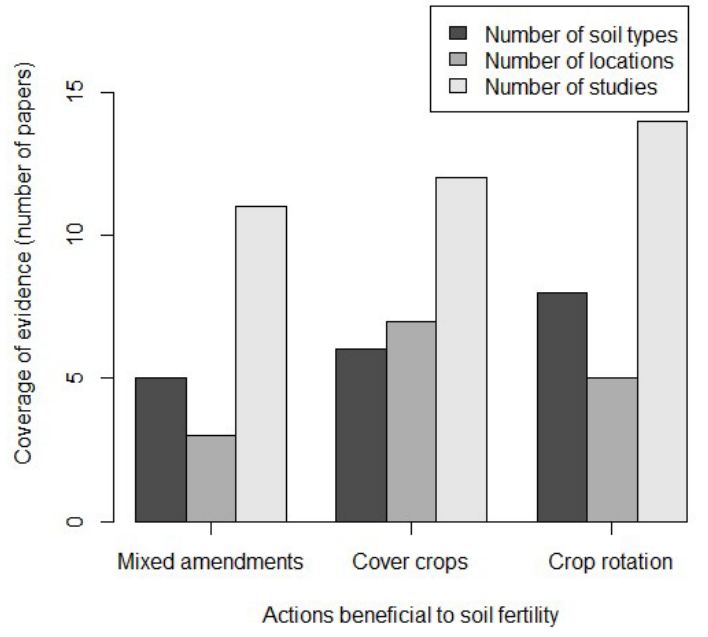

Figure 1. Coverage of soil type, geographical location, and number of studies for the three practices identified as beneficial to soil fertility. Mixed amendments: integrated nutrient management (a mix of organic and inorganic amendments); cover crops: grow cover crops; crop rotation: use crop rotation.

egory was reducing fertilizer and pesticide use, largely due to consequent reductions in crop yields.

Nine of the practices were scored as having "unknown effectiveness". This was largely because few of the studies captured for those practices were replicated or randomized, and therefore many panel members felt unable to comment on the effects of the practices with certainty. Other factors that contributed to "unknown effectiveness" include fewer geographical locations or soil types coverage.

For some practices, several of the practitioners on the Expert Panel were surprised that no negative effects had been reported and questioned why practices such as "change the timing of ploughing" were not common practice if there were no negative side effects. For other practices, panel members identified known negative side effects from their own knowledge and also suggested additional studies, but these were not included in the assessment. The majority of these practices fell into the "trade-offs" category, where evidence suggested that the practices were either beneficial in specific circumstances or considered likely to be beneficial but with strong negative side effects.

We accounted for the negative side effects of practices using a partial Spearman's Rank correlation analysis (Fig. 2). We detected a significant positive relationship between the effectiveness of the practice and certainty of the evidence $\left(r_{\text {partial }}=0.72, n=27, P=<0.001\right)$. There was no significant relationship between effectiveness and negative side effects $\left(r_{\text {partial }}=-0.34, n=27, P=0.09\right)$ or certainty and negative side effects $\left(r_{\text {partial }}=0.17, n=27, P=0.39\right)$.

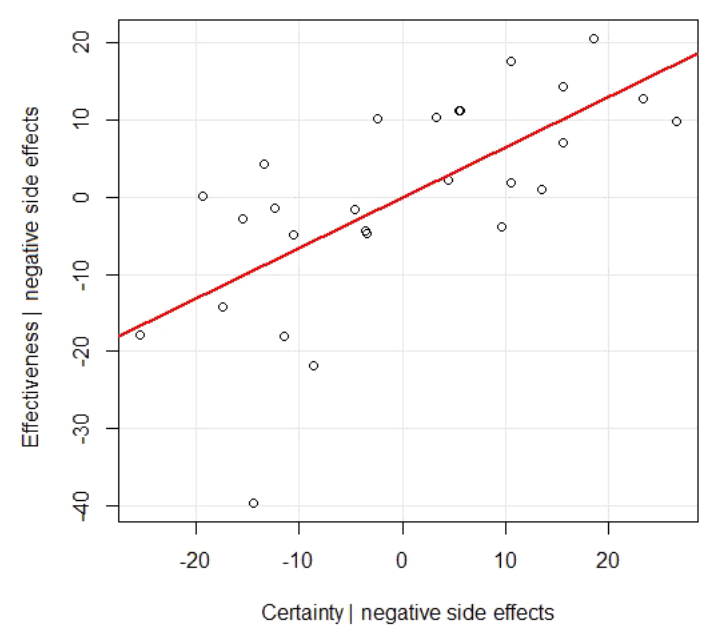

Figure 2. Partial Spearman's rank correlation, determined using the median scores for each of the 27 practices given by the expert panel. Points are plotted according to the first two variables, effectiveness and certainty, while controlling for the third, negative side effects. Effectiveness: effectiveness of the practice; certainty: certainty of the evidence; negative side effects: negative side effects of implementing the practice. Spearman rank correlation coefficient $r_{\mathrm{S}}=0.72, P<0.001$. The red line represents the slope of the least squares line for the residual series.

\section{Discussion}

To clarify research needs and identify effective practices for enhancing soil health, a synopsis of soil literature was carried out and then assessed by experts in the field. The input from both scientists and practitioners helped to identify existing knowledge that should be made more accessible to those who put research into practice (Dicks et al., 2013a) and highlighted a wide spectrum of certainty regarding the practices covered in this review. The three beneficial practices identified by this process, namely integrated nutrient management, "grow cover crops", and "use crop rotation", are well established and have been used for centuries to build soil health. The four practices likely to be beneficial to soil health in agroecosystems, namely growing cover crops beneath the main crop or intercrop, "amend the soil with formulated chemical compounds", "control traffic and traffic timing", and "reduce grazing intensity", were considered to be effective but warranted more evidence before the Expert Panel would state them as conclusively beneficial. The only practice considered harmful to soil health was reducing fertilizer and pesticide use, largely due to its negative effect on crop yields, which the panel felt outweighed any positive effects of reducing fertilizer and pesticide use on biodiversity (Tonitto et al., 2006; Foley et al., 2011; Tscharntke et al., 2012). Perhaps of most significance, however, are the 19 practices falling into the "trade-offs" or "unknown effectiveness" categories, which not only highlights the high level of uncertainty about most practices but also the large num- 
ber of current soil management practises that are based on non-scientific knowledge.

For example in the "trade-offs" category, the conversion to organic farming has been shown to be beneficial for soil health in some situations but not others. Several papers reviewed here had similar findings, showing that there are higher numbers, diversity, or activity of soil organisms under organic management (Liu et al., 2007; Canali et al., 2009, Overstreet et al., 2010; Chaudhry et al., 2012). However, results do not always corroborate each other and can be peculiar to specific crop or soil types. In trials by Malhi et al. (2009), for example, organic management in cereal or pulse crops resulted in lower yields compared to conventional management, whereas two trials in fruit crops in the USA (Jacobsen and Jordan, 2009; Reganold et al., 2010) found that although the fruit was smaller, it was of a higher quality (important for fruit crop value) and more resistant to disease. Also, the addition of municipal wastes has been shown to reduce soil loss and increase water retention (Ros et al., 2001) but has also been shown, depending on the type of waste used, to reduce soil mineral nitrogen (Rahn et al., 2009).

In the "unknown effectiveness" category, only one paper (Beckwith et al., 1998) for the practice "change the timing of manure application" and two (Ramesh and Chandrasekaran, 2004; Ali et al., 2012) for amending the soil with green manures were captured. The three papers only covered two soil types. While partly due to the nature of this review, the fact that so little literature was captured for these practices and the others in this category suggests that far more work needs to be done before a judgement on their effectiveness can be made.

The beneficial practices, such as "use crop rotation", have considerable supporting evidence, and both scientists and practitioners are aware of the merits of these practices across several localities and soil types. The panel felt that there was clear evidence showing that crop rotation is beneficial to soil health, especially when legumes are included in the rotation (Blair and Crocker, 2000; Gregorich et al., 2001; Mäeder et al., 2002; Schjønning et al., 2007; Ryan et al., 2008). Including legumes in rotation can lead to other benefits, such as improved water filtration and reduced competition with weeds (Place et al., 2003). The panel also considered that the evidence for this practice covered a wide range of geographic locations and soil types but showed interest in seeing more studies demonstrating the effect of type and length of rotation on soil biodiversity. Panel members felt that the practice "amend the soil using integrated nutrient management" contributed to a wider range of nutrients and mineralization processes occurring in the soil, which was also found by Palm et al. (1997), as well as providing other benefits for crop productivity, such as weed reduction. This practice also scored highly due to the range of soil types covered by the evidence. The panel considered the evidence for "grow cover crops" to provide good coverage in Europe and scored highly for the effectiveness of this practice. Research has shown that cover cropping over winter can reduce soil and nutrient loss (Ding et al., 2006; Gülser, 2006; Zhang et al., 2007; Zhou et al., 2012). The research was supported by the panel who considered the practice to be most appropriate to the UK when used over winter as post-harvest cover cropping. These Expert Panel responses, and the rich historical literature on the benefits of these practices for soil health, are evidence that they can be regarded as "hot topics" in this field, which are identified by Sutherland et al. (2013) as areas of research that are progressing and, in the case of crop rotation, has been widely implemented for many years (although less used now, or simplified in intensive systems) (Benton et al., 2003).

The "likely to be beneficial" practices were generally considered to be effective with few negative side effects, but the Expert Panel suggested that more evidence was needed, particularly in the form of commercial evidence or case studies, or with specific effects on yields presented. The Spearman's rank correlation suggests that the relationship between negative side effects and the perceived effectiveness of the practice is not as closely correlated as the relationship between effectiveness and certainty of evidence, where more of the variance in the data is accounted for (Chatterjee and Hadi, 2012). The significant positive relationship found between the effectiveness of the practice and certainty of the evidence suggests that, for both scientists and practitioners, increased certainty in the scientific evidence presented for practices resulted in them being considered more effective.

A key finding of our assessment is that it is not yet clear how effective the majority of the reviewed practices are for enhancing soil health. Others have argued that the provision of ecosystem services is limited by a lack of scientific understanding (e.g. Benayas et al., 2009); likewise, our findings suggest that we do not yet have a full understanding of the consequences of practices on soil health. Of the 27 practices reviewed, we found the 9 have "unknown effectiveness", and 10 have trade-offs to their implementation. For practices falling in the "trade-offs" category, there are clear benefits to implementing them; however, they may need to be refined to minimize any negative effects. For example, conversion to organic farming can increase soil organic matter and soil biodiversity (Liu et al., 2007; Birkhofer et al., 2008; Canali et al., 2009; Chaudhry et al., 2012) but can make protecting crops from pests and diseases more difficult and result in lower yields. Planting new hedges reduces soil erosion (Anigma et al., 2002; Mutegi et al., 2008; Donjadee and Tingsanchali, 2013) but could make cultivation more difficult. Amending soil with manures and agricultural composts increases soil organic matter levels (Jones et al., 2006; Celik et al., 2010; Bhattacharyya et al., 2012) but may need to be avoided close to water, due to possible increased nitrate leaching and subsequent water quality problems (Díez et al., 2004). Refining practices was suggested by the practitioners on the panel. For example, refining the practice "reduce fertilizer, pesticide use" to question which pesticides and fertil- 
izers should be reduced, and at what rate, rather than having a blanket reduction could reduce the trade-offs of such a practice. Accessing knowledge from practitioners, which would not necessarily make it into scientific literature, such as the practical barriers to and the specific details of implementing practices, would add more context to the results in this paper. In addition, their knowledge could perhaps provide a wider range of practices for researchers to explore, widening the tools available to enhance soil health. This highlights the importance of two-way knowledge exchange if we are to effectively enhance soil health.

We are aware that the review method we used has limitations, for example only one literature database was used in addition to journal trawling. The Expert Panel suggested studies that were not captured by our searches over the period of the project and were surprised at there being so few papers for some of the practices. The journals trawled represent a spectrum of journals that publish soil-related research and are all well respected in the field. We recognize, however, that there is scope to extend our analysis to consider an even wider range of literature including applied research by industry. The panel also highlighted practices not included in this synopsis that warrant further research, or suggested alternative practices, such as "mob" grazing, where a field is heavily grazed, before removing the animals for a rest period (Bittman and MacCartney, 1994), and grazing of livestock on crop stubble in mixed systems. Another important practice not included in our analysis was integrated pest management (IPM), which is known to have indirect effects on soil health. These practices, which were not included in our analysis, warrant further research.

Our database of references is only a sample of the global literature, but with 132 papers reviewed it nonetheless represents a substantial amount of evidence and demonstrates what can be achieved within a short time frame. Previous research has queried the use of the Delphi technique as a stand-alone decision-making tool (Angus et al., 2003), so the next step would be to expand the review process and Delphi methods (i.e. a larger Expert Panel with additional rounds of scoring) to capture the full breadth of available evidence for soil health (Rowe and Wright, 2011). For some practices the range of technology used, for example in formulated chemical amendments, highlights the difficulty in comparing studies; what might be suitable in one location on one soil type may not be appropriate for others. The condition of a site also needs to be taken into account when recommending practices, given that the impact of various practices will vary depending on many factors, including soil type, the extent that a soil is degraded, and local climate. Although not useful for forming broad applications, reviews such as this could lead to targeted "best-fit" approaches more beneficial to local soil health, an approach found by Giller et al. (2010) to be better for different types of farms. The review also provides an informative starting point on appropriate practices for improved soil health.

\section{Conclusions}

This review provides a useful case study of a method to incorporate expert knowledge into the implementation of evidence-based practice to improve soil health in agroecosystems. Not only have we highlighted several ways of maintaining or improving soil health that are based on scientific evidence, but we also identify a high level of uncertainty surrounding many interventions that are widely used to maintain soil health. Further, our assessment has also identified major research gaps and areas of uncertainty in relation to the effectiveness of certain interventions, which may prove to be a barrier to implementing practices. Expanding the scope of the review in future work may help to identify some of the uncertainty surrounding practices and refine what further research is needed. Agricultural intensification is required to improve food security; however, this needs to be done in a sustainable way if we are to have more resilient agricultural systems in the face of climate change. By implementing the beneficial practices as assessed above and addressing some of the gaps in our knowledge, we could go some way to restoring functional biodiversity and associated ecosystem services for good soil health in agroecosystems.

\section{The Supplement related to this article is available online at doi:10.5194/soil-2-511-2016-supplement.}

Author contributions. The project was initiated by William J. Sutherland and Richard D. Bardgett. Georgina Key and Mike G. Whitfield carried out the systematic review, with input from Richard D. Bardgett, Lynn V. Dicks, and William J. Sutherland. Georgina Key carried out the Delphi process with contributions from Lynn V. Dicks. Ranking was carried out by Julia Cooper, Franciska T. De Vries, Martin Collison, Thanasis Dedousis, Richard Heathcote, Brendan Roth, S. A. M. Shamal, Andrew Molyneux, and Wim H. Van der Putten and collated by Georgina Key. Georgina Key carried out the statistical correlations with help from Mike G. Whitfield. Georgina Key prepared the paper with contributions from all co-authors.

Acknowledgements. This work was supported by the Natural Environment Research Council (grant number NE/K001191/1). William J. Sutherland is funded by Arcadia. Thanks to Joscelyn Ashpole for her contributions to the process and to Phil Donkersley for his statistical advice.

Edited by: S. Keesstra

Reviewed by: J. Idowu and I. Stavi 


\section{References}

Ali, R. I., Awan, T. H., Ahmad, M., Saleem, M. U., and Akhtar, M.: Diversification of rice-based cropping systems to improve soil fertility, sustainable productivity and economics, J. Animal Plant Sci., 22, 108-112, 2012.

Allman, M., Jankovský, M., Messingerová, V., Allmanová, Z., and Ferenčik, M.: Compaction of various Central European forest soils caused by traffic of machines with various chassis, Forest Systems, 24, 1-10, 2015.

Angus, A. J., Hodge, I. D., McNally, S., and Sutton, M. A.: The setting of standards for agricultural nitrogen emissions: a case study of the Delphi technique, J. Environ. Manage., 69, 323-337, 2003.

Anigma, S. D., Stott, D. E., O’Neill, M. K., Ong, C. K., and Weesies, G. A.: Use of calliandra-Napier grass contour hedges to control erosion in central Kenya, Agr. Ecosyst. Environ., 91, 15-23, 2002.

Amundson, R., Berhe, A. A., Hopmans, J. W., Olson, C., Sztein, A. E., and Sparks, D. L.: Soil and human security in the $21^{\text {st }}$ century, Science, 348, 647-653, 2015.

Bardgett, R. D.: Causes and consequences of biological diversity in soil, Zoology, 105, 367-374, 2002.

Bardgett, R. D.: Earth Matters, Oxford University Press, Oxford, 2016.

Bardgett, R. D. and van der Putten, W. H.: Belowground biodiversity and ecosystem functioning, Nature, 515, 505-511, 2014.

Barrios, E.: Soil biota, ecosystem services and land productivity, Ecol. Econ., 1, 1-17, 2007.

Beckwith, C. P., Cooper, J., Smith, K. A., and Shepherd, M. A.: Nitrate leaching loss following application of organic manures to sandy soils in arable cropping. I. Effects of application time, manure type, overwinter crop cover and nitrification inhibition, Soil Use Manage., 14, 123-130, 1998.

Benayas, J. M. R., Newton, A. C., Diaz, A., and Bullock, J.: Enhancement of biodiversity and ecosystem services by ecological restoration: A meta-analysis, Science, 325, 1121-1124, 2009.

Benton, T. G., Vickery, J. A., and Wilson, J. D.: Farmland biodiversity: is habitat heterogeneity the key?, Trends Ecol. Evol., 18, 182-188, 2003.

Beylich, A., Oberholzer, H. R., Schrader, S., Höper, H., and Wilke, B. M.: Evaluation of soil compaction effects on soil biota and soil biological processes in soils, Soil Till. Res., 109, 133-143, 2010.

Bhattacharyya, P., Roy, K. S., Neogi, S., Chakravorti, S. P., Behera, K. S., Das, K. M., Bardhan, S., and Rao, K. S.: Effect of long-term application of organic amendment in relation to global warming potential and biological activities in tropical flooded soil planted to rice, Nutr. Cycl. Agroecosyst., 94, 273-285, 2012.

Birkhofer, K., Bezemer, M. T., Bloem, J., Bonkowski, M. Christensen, S., Dubois, D., Ekelund, F., Fliessbach, A., Gunst, L., and Hedlund, K. L. U., Maeder, P., Mikola, J., Robin, C., Setala, H., Tatin-Froux, F., Van der Putten, W. H., and Scheu, S.: Long-term organic farming fosters below and aboveground biota: Implications for soil quality, biological control and productivity, Soil Biol. Biochem., 40, 2297-2308, 2008.

Bittman, S. and MacCartney D. H.: Evaluating alfalfa cultivars and germplasms for pastures using the mob-grazing technique, Can. J. Plant Sci., 74, 109-114, 1994.
Blair, N. and Crocker, G. J.: Crop rotation effects on soil carbon and physical fertility of two Australian soils, Aust. J. Soil Sci., 38, 71-84, 2000.

Boulkedid, R., Abdoul, H., Loustau, M., Sibony, O., and Alberti, C. Using and reporting the Delphi Method for selecting healthcare quality indicators: A systematic review, PLoS One, 6, 1-9, 2011.

Burgman, M., Anna, C., Godden, L., Gregory, R., McBride, M., Flander, L., and Maguire, L.: Redefining expertise and improving ecological judgment, Conserv. Lett., 4, 81-87, doi:10.1111/j.1755-263X.2011.00165.x, 2011.

Canali, S., Bartolomeo, E. Di, Trinchera, A., Nisini, L., Tittarelli, F., Intrigliolo, F., Roccuzzo, G., and Calabretta, M. L.: Effect of different management strategies on soil quality of citrus orchards in Southern Italy, Soil Use Manage., 25, 34-42, 2009.

Celik, I., Gunal, H., Budak, M., and Akpinar, C.: Effects of longterm organic and mineral fertilizers on bulk density and penetration resistance in semi-arid Mediterranean soil conditions, Geoderma, 16, 236-243, 2010.

Chatterjee, S. and Hadi, A. S. (Eds.): Regression Analysis by Example, 5th Edn., John Wiley \& Sons, Inc., Hoboken, New Jersey, USA, and Canada, 8-9, 2012.

Chaudhry, V., Rehman, A., Mishra, A., Chauhan, P. S., and Nautiyal, C. S.: Changes in bacterial community structure of agricultural land due to long-term organic and chemical amendments, Microb. Ecol., 64, 450-460, 2012.

Crittenden, S. J., Poot, N., Heinen, M., van Balen, D. J. M., and Pulleman, M. M.: Soil physical quality in contrasting tillage systems in organic and conventional farming, Soil Till. Res., 154, 136-144, 2015.

Defra: Safeguarding our soils: A strategy for England, Department for the Environment, Food and Rural Affairs, London, UK, 48 pp., available at: https://www.gov.uk/ government/uploads/system/uploads/attachment_data/file/ 69261/pb13297-soil-strategy-090910.pdf (last access: 7 December 2015), 2009.

De Vries, F. T., Liiri, M. E., Bjørnlund, L., Bowker, M. A., Christensen, S., Setälä, H. M., and Bardgett, R. D.: Land use alters the resistance and resilience of soil food webs to drought, Nat. Clim. Change, 2, 276-280, doi:10.1038/nclimate1368, 2012.

Dicks, L. V., Hodge, I., Randall, N. P., Scharlemann, J. P. W., Siriwardena, G. M., Smith, H. G., Smith, R. K., and Sutherland, W. J.: A Transparent process for "evidence-informed" policy making, Conserv. Lett., 7, 119-125, 2013a.

Dicks, L. V., Abrahams, A., Atkinson, J., Biesmeijer, J., Bourn, N., Brown, C., Brown, M. J. F., Carvell, C., Connolly, C., Cresswell, J. E., Croft, P., Darvill, B., De Zylva, P., Effingham, P., Fountain, M., Goggin, A., Harding, D., Harding, T., Hartfield, C., Heard, M. S., Heathcote, R., Heaver, D., Holland, J., Howe, M., Hughes, B., Huxley, T., Kunin, W. E., Little, J., Mason, C., Memmott, J., Osborne, J., Pankhurst, T., Paxton, R. J., Pocock, M. J. O., Potts, S. G., Power E. F., Raine, N. E., Ranelagh, E., Roberts, S., Saunders, R., Smith, K., Smith, R. M., Sutton, P., Tilley, L. A. N., Tinsley, A., Tonhasca, A., Vanbergen, A. J., Webster, S., Wilson, A., and Sutherland, W. J.: Identifying key knowledge needs for evidence-based conservation of wild insect pollinators: a collaborative cross-sectoral exercise, Insect Conserv. Divers., 6, 435-446, 2013b.

Díez, J. A., henaiz, P., Muñoz, M. J., de la Torre, A. and Vallejo, A.: Impact of pig slurry on soil properties, water salinization, ni- 
trate leaching and crop yield in a four-year experiment in Central Spain, Soil Use Manage., 20, 444-450, 2004.

Ding, G., Liu, X., Herbert, S., Novak, J., Amarasiriwardena, D., and Xing, B.: Effect of cover crop management on soil organic matter, Geoderma, 130, 229-239, 2006.

Don, A., Schumacher, J., and Freibauer, A.: Impact of tropical land use change on soil organic carbon stocks - a meta-analysis, Global Change Biol., 17, 1658-1686, 2010.

Donjadee, S. and Tingsanchali, T.: Reduction of runoff and soil loss over steep slopes by using vetiver hedgerow systems, Paddy Water Environ., 11, 573-581, 2013.

FAO and ITPS: Status of the World's Soil Resources (SWSR) Technical Summary, Food and Agriculture Organization of the United Nations and Intergovernmental Technical Panel on Soils, Rome, Italy, 2015.

Foley, J. A., Ramankutty, N., Brauman, K. A., Cassidy, E. S., Gerber, J. S., Johnston, M., Mueller, N. D., O’Connell, C., Ray, D. K., West, P.C., Balzer, C., Bennett, E. M., Carpenter, S. R., Hill, J., Monfreda, C., Polasky, S., Rockström, J., Sheehan, J., Siebert, S., Tilman, D., and Zaks, D. P. M.: Solutions for a cultivated planet, Nature, 478, 1-6, 2011.

Giller, K. E., Tittonell, P., Rufino, M. C., van Wijk, M. T., Zingore, S., Mapfumo, P., Adjei-Nsiah, S., Herrero, M., Chikowo, R., Corbeels, M., Rowe, E. C., Baijukya, F., Mwijage, A., Smith, J., Yeboah, E., van der Burg, W. J., Sanogo, O. M., Misikom, M., de Ridder, N., Karanja, S., Kaizzi, C., K'ungu, J., Mwale, M., Nwaga, D., Pacini, C., and Vanlauwe, B.: Communicating complexity: Integrated assessment of trade-offs concerning soil fertility management within African farming systems to support innovation and development, Agricult. Syst., 104, 1-13, 2010.

Glover, J. D., Reganold, J. P., Bell, L.W., Borevitz, J., Brummer, E. C., Buckler, E. S., Cox, C. M., Cox, T. S., Crews, T. E., Culman, S. W., DeHaan, L. R., Eriksson, D., Gill, B., Holland, J., Hu, F. Y., Hulke, B., Ibrahim, A., Jones, S., Murray, S., Ploschuk, E., Sacks, E. J., Snapp, S., Tao, D. Y., Van Tassel, D., Wade, L., Wyse, D., and Xu, Y.: Increased food and ecosystem security via perennial grains, Science, 328, 1638-1639, 2010.

Gregorich, E. G., Drury, C. F., and Baldock, J. A.: Changes in soil carbon under long-term maize in monoculture and legume-based rotation, Can. J. Soil Sci., 81, 21-31, 2001.

Gülser, C.: Effect of forage cropping treatments on soil structure and relationships with fractal dimensions, Geoderma, 131, 3344, 2006.

Hasson, F., Keeney, S., and McKenna, H.: Research guidelines for the Delphi survey technique, J. Adv. Nurs., 32, 1008-1015, 2000.

Hsu, C. C. and Sandford, B. A.: The Delphi technique: making sense of consensus, Pract. Assess. Res. Eval., 12, 1-8, 2007.

Hutchings, A. and Raine, R.: A systematic review of factors affecting the judgments produced by formal consensus development methods in health care, J. Health Serv. Res. Policy, 11, 172-179, 2006.

Jacobsen, K. L. and Jordan, C. F.: Effects of restorative agroecosystems on soil characteristics and plant production on a degraded soil in the Georgia Piedmont, USA, Renew. Agricult. Food Syst., 24, 186-196, 2009.

Jones, J. and Hunter, D.: Consensus methods for medical and health services research, Brit. Med. J., 311, 376-380, 1995.
Jones, S. K., Rees, R. M., Kosmas, D., Ball, B. C., and Skiba, U. M.: Carbon sequestration in a temperate grassland; management and climatic controls, Soil Use Manage., 22, 132-142, 2006.

Keesstra, S. D., Bouma, J., Wallinga, J., Tittonell, P., Smith, P., Cerdà, A., Montanarella, L., Quinton, J. N., Pachepsky, Y., van der Putten, W. H., Bardgett, R. D., Moolenaar, S., Mol, G., Jansen, B., and Fresco, L. O.: The significance of soils and soil science towards realization of the United Nations Sustainable Development Goals, SOIL, 2, 111-128, doi:10.5194/soil-2-1112016, 2016.

Key, G., Whitfield, M., Dicks, L. V., Sutherland, W. J. and Bardgett, R. D.: Enhancing soil fertility, in: What works in conservation, edited by: Sutherland, W. J., Dicks, L. V., Ockendon, N., and Smith, R. K., Open Book Publishers, Cambridge, UK, 317-318, 2015.

Kibblewhite, M. G., Ritz, K., and Swift, M. J.: Soil health in agricultural systems, Philos. T. Roy. Soc. B, 363, 685-701, 2008.

Kim, S.: ppcor: Partial and Semi-partial (Part) correlation, R package, version 1.0, http://CRAN.R-project.org/package=ppcor (last access: 15 March 2016), 2012.

Lal, R.: Soil Degradation, in: Advances in soil science, in: Vol. 11, edited by: Lal, R. and Stewart, B. A., Springer-Verlag, New York, 129-172, 1990.

Lal, R.: Soil degradation as a reason for inadequate human nutrition, Food Security, 1, 45-57, doi:10.1007/s12571-009-0009-z, 2009.

Lamarque, P., Tappeiner, U., Turner, C., Steinbacher, M., Bardgett, R. D., Szukis, U., Schermer, M., and Lavorel, S.: Stakeholder perceptions of grassland ecosystem services in relation to knowledge on soil fertility and biodiversity, Reg. Environ. Change, 11, 791-804, 2011.

Lavelle, P., Decaëns, T., Aubert, M., Barot, S., Blouin, M., Bureau, F., Margerie, P., Mora, P., and Rossi, J. P.: Soil invertebrates and ecosystem services, Eur. J. Soil Biol., 42, S3-S15, 2006.

Lipper, L., Thornton, P., Campbell, B. M., Baedeker, T., Braimoh, A., Bwalya, M., Caron, P., Cattaneo, A., Garrity, D., Henry, K., Hottle, R., Jackson, L., Jarvis, A., Kossam, F., Mann, W., McCarthy, N., Meybeck, A., Neufeldt, H., Remington, T., Sen, P. T., Sessa, R., Shula, R., Tibu, A. and Torquebiau, E. F.: Climatesmart agriculture for food security, Nat. Clim. Change, 4, 10681072, 2014.

Liu, B., Tu, C., Hu, S., Gumpertz, M., and Ristaino, J. B.: Effect of organic, sustainable, and conventional management strategies in grower fields on soil physical, chemical, and biological factors and the incidence of Southern blight, Appl. Soil Ecol., 37, 202214, 2007.

Maeder, P., Fließach, A., Dubois, D., Gunst, L., Fried, P., and Niggli, U.: Soil fertility and biodiversity in organic farming, Science, 296, 1694-1697, 2002.

Malhi, S. S., Brandt, S. A., Lemke, R., Moulin, A. P., and Zentner, R. P.: Effects of input level and crop diversity on soil nitrate-N, extractable $\mathrm{P}$, aggregation, organic $\mathrm{C}$ and $\mathrm{N}$, and nutrient balance in the Canadian Prairie, Nutr. Cycl. Agroecosyst., 84, 1-22, 2009.

Marmo, L.: The EU's Soil Thematic Strategy and ongoing activities, UK Soil Association National Soil Symposium, 1-15, available at: https://www.soilassociation.org/LinkClick.aspx? fileticket $=\ln 2 \mathrm{CKz}$ IPt0\%3D\&tabid $=1886$, last access: 1 December 2012 . 
Martinez-Casasnovas, J. A. and Ramos, M. C.: Soil alteration due to erosion, ploughing and levelling of vineyards in north east Spain, Soil Use Manage., 25, 183-192, 2009.

Mukherjee, N., Sutherland, W. J., Dicks, L. V., Hugé, J., Koedam, N., and Dahdouh-Guebas, F.: Ecosystem service valuations of mangrove ecosystems to inform decision making and future valuation exercises, PLOS ONE, 9, 1-9, 2014.

Mukherjee, N., Hugé, J., Sutherland, W. J., McNeill, J., Van Opstal, M., Dahdouh-Guebas, F., and Koedam, N.: The Delphi technique in ecology and biological conservation: applications and guidelines, Meth. Ecol. Evol., 6, 1097-1109, 2015.

Mutegi, J. K., Mugendi, D. N., Verchot, L. V., and Kung'u, J. B.: Combining napier grass with leguminous shrubs in contour hedgerows controls soil erosion without competing with crops, Agroforest. Syst., 74, 1-13, 2008.

Nunes, A. D., de Almeida, A. C., and Coelho, C. O. A.: Impacts of land use and cover type on runoff and soil erosion in a marginal area of Portugal, Appl. Geogr., 31, 687-699, 2011.

Overstreet, L. F., Hoyt, G. D., and Imbriani, J.: Comparing nematode and earthworm communities under combinations of conventional and conservation vegetable production practices, Soil Till. Res., 110, 42-50, 2010.

Palm, C. A., Myers, R. J. K., and Nandwa, S. M. Combined use of organic and inorganic nutrient sources for soil fertility maintenance and replenishment, Replenishing Soil Fertility in Africa, Special publication 51, American Society of Agronomy and Soil Science Society of America, Madison, USA, 193-217, 1997.

Philippot, L., Raaijmakers, J. M., Lemanceau, P., and van der Putten, W.: Going back to the roots: the microbial ecology of the rhizosphere, Nat. Rev. Microbiol., 11, 789-799, 2013.

Pimentel, D., Harvey, C., Resosudarmo, P., Sinclair, K., Kurz, M., McNair, M., Crist, S., Shpritz, L., Fitton, L., Saffouri, R., and Blair, R.: Environmental and Economic Costs of Soil Erosion and Conservation Benefits, Science, 267, 1117-1123, 1995.

Place, F., Barrett, C. B., Freeman, H. A., Ramisch, J. J., and Vanlauwe, B.: Prospects for integrated soil fertility management using organic and inorganic inputs: evidence from smallholder African agricultural systems, Food Policy, 28, 365-378, 2003.

Rahn, C. R., Bending, G. D., Lillywhite, R. D., and Turner, M. K.: Co-incorporation of biodegradable wastes with crop residues to reduce nitrate pollution of groundwater and decrease waste disposal to landfill, Soil Use Manage., 25, 113-123, 2009.

Ramesh, K. and Chandrasekaran, B.: Soil Organic Carbon Build-up and Dynamics in Rice-Rice Cropping Systems, J. Agron. Crop Sci., 190, 21-27, 2004.

R Core Team: R: A language and environment for statistical computing, R Foundation for Statistical Computing, Vienna, Austria, http://www.R-project.org/ (last access: 15 March 2016), 2014.

Reganold, J. P., Andrews, P. K., Reeve, J. R., Carpenter-Boggs, L., Schadt, C. W., Alldredge, J. R., Ross, C. F., Davies, N. M., and Zhou, J.: Fruit and soil quality of organic and conventional strawberry agroecosystems, PloS ONE, 5, 1-14, 2010.

Ros, M., Garcia, C., and Hernandez, T.: The use of urban organic wastes in the control of erosion in a semiarid Mediterranean soil, Soil Use Manage., 17, 292-293, 2001.

Rowe, G. and Wright, G.: The Delphi technique as a forecasting tool: issues and analysis, Int. J. Forecast., 15, 353-375, 1999.
Rowe, G. and Wright, G.: The Delphi technique: Past, present and future prospects - Introduction to the special issue, Technol. Forecast. Social Change, 78, 1487-1490, 2011.

Ryan, J., Masri, S., İbriçi, H., Singh, M., Pala, M., and Harris, H. C.: Implications of cereal-based crop rotation, nitrogen fertilisation, and stubble grazing on soil organic matter in a Mediterraneantype environment, Turk. J. Agr. Forest., 32, 289-297, 2008.

Schjønning, P., Munkholm, L. J., Elmholt, S., and Olesen, J. E.: Organic matter and soil tilth in arable farming: Management makes a difference within 5-6 years, Agr. Ecosyst. Environ., 122, 157172, 2007.

SEPA - Scottish Environment Protection Agency: Threats to soil quality, available at: http://www.sepa.org.uk/land/soil/threats_ to_soil_quality.aspx, last access: 1 December 2012.

Sutherland, W. J.: Predicting the ecological consequences of environmental change: a review of the methods, J. Appl. Ecol., 43, 599-616, 2006.

Sutherland, W. J., Pullin, A. S., Dolman, P. M., and Knight, T. M.: The need for evidence-based conservation, Trends Ecol. Evol., 19, 305-308, 2004.

Sutherland, W. J., Goulson, D., Potts, S. G., and Dicks, L. V.: Quantifying the impact and relevance of scientific research, PLoS ONE, 6, 1-10, 2011.

Sutherland, W. J., Freckleton, R. P., Godfray, H. C. J., Beissinger, S. R., Benton, T., Cameron, D. D., Carmel, Y., Coomes, D. A., Coulson, T., Emmerson, M. C., Hails, R. S., Hays, G. C., Hodgson, D. J., Hutchings, M. J., Johnson, D., Jones, J. P. G., Keeling, M. J., Kokko, H., Kunin, W. E., Lambin, X., Lewis, O. T., Malhi, Y., Mieszkowska, N., Milner-Gulland, E. J., Norris, K., Phillimore, A. B., Purves, D. W., Reid, J. M., Reuman, D. C., Thompson, K., Travis, J. M. J., Turnbull, L. A., Wardle, D. A., and Wiegand, T.: Identification of 100 fundamental ecological questions, J. Ecol., 101, 58-67, 2013.

Sutherland, W. J., Dicks, L. V., Ockendon, N., and Smith, R. K. (Eds.): What Works in Conservation, Open Book Publishers, Cambridge, UK, 2015.

Terranova, O., Antronico, L., Coscarelli, R., and Iaquinta, P.: Soil erosion risk scenarios in the Mediterranean environment using RUSLE and GIS: An application model for Calabria (southern Italy), Geomorphology, 112, 228-245, 2009.

Tonitto, C., David, M. B., and Drinkwater, L. E.: Replacing bare fallows with cover crops in fertilizer-intensive cropping systems: A meta-analysis of crop yield and N dynamics, Agr. Ecosyst. Environ., 112, 58-72, 2006.

Tscharntke, T., Clough, Y., Wanger, T. C., Jackson, L., Motzke, I., Perfecto, I., Vandermeer, J. and Whitbread, A.: Global food security, biodiversity conservation and the future of agricultural intensification, Biol. Conserv., 151, 53-59, 2012.

Tsiafouli, M. A., Thebault, E., Sgardelis, S. P., de Ruiter, P. C., van der Putten, W. H., Birkhofer, K., Hemerik, L., de Vries, F. T., Bardgett, R. D. and Brady, M. V.: Intensive agriculture reduces soil biodiversity across Europe, Global Change Biol., 21, 973985, 2016.

Turbé, A., De Toni, A., Benito, P., Lavelle, P., Lavelle, P., Camacho, N. R., van der Putten, W. H., Labouze, E., and Mudgal, S.: Soil bio-diversity: functions, threats and tools for policy makers, Rapport de synthèse, Bio Intelligence Service, IRD, and NIOO, Report for European Commission (DG Environment), 127-141, 2010. 
Wall, D. H., Bardgett, R. D., Behan-Pelletier, V., Herrick, J. E., Jones, H., Ritz, K., Six, J., Strong, D. R., and van der Putten, W. H. (Eds.): Soil Ecology and Ecosystem Services, Oxford University Press, Oxford, 2012.

Walsh, J., Dicks, L. V. and Sutherland, W. J.: The effect of scientific evidence on conservation practitioners' management decisions. Conservation Biology, 0 (0), 1-11, 2013.
Zhang, W., Ricketts, T. H., Kremen, C., Carney, K., and Swinton, S. M.: Ecosystem services and dis-services to agriculture, Ecol. Econ., 64, 253-260, 2007.

Zhou, X., Chen, C., Wu, H., and Xu, Z.: Dynamics of soil extractable carbon and nitrogen under different cover crop residues, J. Soils Sediments, 12, 844-853, 2012. 